\title{
Media in human life - their role and significance for social development and functioning
}

\section{KEYWORDS}

educational environment, educational impact, media, media messages, virtual reality

\begin{abstract}
Hanna Rugała, Media in human life - their role and significance for social development and functioning. Culture Society - Education no. 1(19) 2021, Poznań 2021, pp. 111-118, Adam Mickiewicz University Press. ISSN 23000422. DOI 10.14746/kse.2021.19.8

The media serve as a tool used for transmitting information, as well as a centre of social life. There is no doubt that over time they also became one of the most dominant areas of activity for children and young people. The paper aims to present the role and importance of the media in the lives of every human being, with particular emphasis on the young generation. The author takes a closer look at the media as an educational environment shaping society's behaviour and way of thinking. The paper also outlines several examples of the impact and consequences that the use of mass media has on health and social functioning.
\end{abstract}

\section{Introduction}

For many years, the media have been a common space for social life, but functioning while staying online all the time still requires awareness-raising and analysis of its impact on proper development. It is hard to come up with an explicit conclusion on whether the world of information technology is working for the benefit or to the detriment of society; after all, one cannot deny the significance

\footnotetext{
* ORCID https://orcid.org/0000-0002-4100-4986.
} 
of all the achievements, benefits and development stimulated by media and information technology to date; nor can technological progress or its impact on our lives be dismissed, even if a clear assessment of its impact on social relations poses a challenge. This technological dualism is an area of analysis for scholars working in various scientific disciplines. In the case of teachers, the most interesting issues revolve around human beings and changes in personality, the way of thinking and behaviour which are directly or indirectly caused by the use of media. This paper outlines the significance of media as an environment of human life, in particular as an educational environment for children and young people. The author points out various consequences of their use, including the risks posed by the media concerning the functioning of the family, health, education of the young generation and proper functioning in society.

The definition of the media is neither unambiguous nor standardised, due to the changes it undergoes as technologies develop. The term media can be approached from two points of view in terms of the scope of its meaning. In a broad sense, the term concerns "all technologies, which enable recording and transmitting information in time and space" (Huk, 2011: 19-20). Agnieszka Rogulska cites a more elaborate definition of the media, originally coined by Wacław Strykowski - "Media concern all kinds of materials, objects, devices, programmes that transmit information from sender to recipient in the form of messages and trigger various types of activities among the recipients - intellectual, emotional, verbal, and manual. Thus, media include: textbooks, magazines, images on boards and screens, videos, radio, television, computers, multimedia software, and the Internet" (Rogulska, 2012: 20). A narrower approach to this concept entails focusing on the information technology devices that enable direct or indirect interaction and communication between sender and recipient, which includes the Internet, television, computer, video games, mobile phone, and television commercials (Rogulska, 2012: 21) This paper focuses mainly on television and the Internet, since, according to the studies and surveys ${ }^{1}$ (Omyła-Rudzka, Feliksiak, 2019: 1-2), they are characterised by the highest frequency of use as the source of current information about the world.

\section{Media as a living environment}

Media have grown to become the main area of functioning for humans, as well as a source of experiences influencing the way of thinking, type and intensity of experiencing emotions and behaviour. Through the mass media, people get access

\footnotetext{
${ }^{1}$ Study source: CBOS.
} 
to news and information of various kinds, which undoubtedly have an impact on shaping individuals' attitudes. The virtually unlimited availability of media has had an unprecedented result in the fact that starting from an early age, children's experiences are mostly visual and media-oriented in nature (Nowicka, 2012b: 157). These days, however, one can also bring up media as an educational environment in the context of a person's lifelong functioning in virtual reality. With the development of technology, new spaces for existence emerge, with the profile and scope of the activities that one can engage in with the help of mass media changing constantly. From a medium which used to fulfil the role of a source of entertainment and information, the media turned into a centre for establishing and maintaining social contacts, a workplace, space for charitable activities, exchange of views and ideas, as well as a source and means of cultural transmission. The media also play an important social role in several different dimensions as an educational environment, since first and foremost they shape the individual and collective imagination. What is more, they also offer a space where public issues, both local and global, depending on the reach of the media, can be presented, discussed and resolved, thus influencing the entirety of our lives, not only in the social aspect, but also in terms of individual choices and actions. Influence is "a long-term process that manifests itself in changes in attitudes, views, behaviours, as well as aesthetic and moral judgements" (author unknown ${ }^{2}, 2010$ ). The type and intensity of the impact of the same information broadcast by the media may be different for various individuals. This difference stems from the viewer's unique personal experiences, personality, predispositions, and indirect factors that enhance, limit, or eliminate the effectiveness of media influence on humans (author unknown, 2010). There are many classifications of the media's impact on human beings and their surrounding reality. In the context of an individual, one of the most noteworthy models of media influence encompasses direct, deferred, subconscious and external influence (author unknown, 2010). Direct influence is the immediate impact on the emotions and thought process of the recipient of a media message. Deferred or cumulative impact is based on the principle of deepening - the media message has a slight impact, which then adds up to earlier impacts and after some time causes significant changes in the recipient's attitude. Subconscious influence works in a similar way to cumulative influence: initially, the recipient is not aware of this influence, which is why they may be indifferent to the information that they see; however, after some time, in an appropriate context, emotional tension triggered

\footnotetext{
2 Source: media education blog, http://technikamedialna.blogspot.com/2010/08/2212-media-jako-srodowisko-wychowawcze.html, accessed: 30.05.2020.
} 
by a given media message is released. External influence works on the basis of people's natural tendency to imitate, and as a result, it affects the psycho-emotional state through content that presents moral and ethical attitudes.

If media messages can have such a broad range of influences on people's attitudes and how they function in the world, looking at the functions that the media play in the modern world is just as worthwhile. Citing Małgorzata Łobacz, we can distinguish the basic functions of media relevant to the pedagogical aspect (Nowicka, 2012b: 167-170.) The information function satisfies the individual's need and right to information by providing the opportunity to participate in events from around the world. The educational function may be approached in two different ways - as intentional, previously thought-out and planned educational activity, as well as an unintentional push to adopt certain attitudes by presenting behavioural models using the example of protagonists and characters. The entertainment function concerns providing entertainment by presenting theatre, film, music and literature, so that the media has a compensatory and supportive role in relieving stress and tension. The integration function enables bringing together a group of recipients of the same content. The opinion-forming function is realised through forming the opinions of the recipients of media messages, promotes growth and activity, diversifies interests and pushes the individuals to change.

In conclusion, the media serve not only as a tool for conveying information, but also as a living space created for and by human beings. The virtual world affects people and their ways of functioning on par with the real world. Regardless of the place of interaction, whether online or in the real world, the person is always the same, and as a result, their actions and behaviours can spill over between these two spaces. For these reasons, the clear division between the real world and virtual world is becoming increasingly invisible, as the boundaries of the online and offline worlds are starting to blur, making it difficult for us to distinguish between moments of unambiguous presence in the virtual and real worlds.

\section{Media and spheres of human development and functioning}

As the author has already noted, modern media is more than a source of entertainment and information. "Content presented by the media enables the audiences to align themselves with the contemporary world, accelerate changes in education, sensitise them to culture, and facilitate the formation of social ties" (Nowicka, 2012b: 157). The media shape world views, behaviour patterns and attitudes 
affecting human functioning. This impact can be either positive or negative, with benefits or losses to a person's physical, mental and social condition, which is why it is worth taking a brief look at the issue of the media's influence on other spheres of life. Due to the sheer multitude of these spheres - a person as a child, parent, student, employee, employer, consumer, gamer, etc. - only selected examples of opportunities and threats of the media for children and adolescents in the area of family, education and health will be presented.

\section{Media and the family}

The media can have an impact on the process of family integration thanks to the family spending time together while using media and receiving media messages. By spending their free time in front of the TV or on the Internet, individual family members can get to know each other's interests, find common topics for conversation and exchange views on the content they have watched, which helps bring the family closer, strengthen their ties and shape identity. However, the media can also contribute to the disintegration of the family. This happens when the use of modern technology leads the household members to become shut in their own personal worlds, which results in a loosening of bonds and a limiting of mutual contacts with other family members. Such a phenomenon can lead to serious negative effects regarding the proper social and moral development of children and youth (Nowicka, 2012b: 167-170).

\section{Media and education}

The media contribute to the dissemination of knowledge thanks to the high availability of information and modern technologies that facilitate its popularisation and acquisition. Dynamic technological progress promotes the development of civilisation, which forces individuals to keep their knowledge and information up to date. This process is fostered by the media by presenting the achievements of science, technology and art. By doing so, they make it possible to equalise the level of knowledge of children from different backgrounds, while expanding their collective cognitive field by giving them better access to the surrounding reality (Nowicka, 2012b: 168). Excessive or inappropriate use of media can result in intellectual passivity, leading to reduced intellectual effort, independent thinking and understanding of content; neglect of school duties, impoverishment of vocabulary, neglect of the development of correct pronunciation, as well as disruption of cognitive functions - in some cases, this may lead to a lack of opportunities to continue education (Nowicka, 2012b: 171). 


\section{Media and health}

Improper or excessive media use can also result in negative consequences for one's health. These changes may be temporary or permanent, but they are always destructive, both physically and psychologically. The most significant threats to physical health include visual impairment, postural defects, scoliosis, decreased mobility, and obesity (Nowicka, 2012b: 171). The main threats to mental health include media addiction, weakening of the nervous system manifested by fatigue, distraction, anxiety attacks, memory disorders; neurological dysfunctions - screen epilepsy, neuroses; reduced intellectual capacity - mental laziness and reduced abstract thinking skills (Nowicka, 2012b: 171-172).

\section{Media and social behaviour}

Media addiction affects not only physical and mental health but also social behaviour. This concerns the dangers and risks connected with improper social functioning outside the virtual world - problems with interpersonal relations, social isolation, sense of alienation and loneliness (Jopek, 2018: 35). One can also distinguish risks associated with the disruption or weakening of interpersonal contacts (with the family, peers or teachers) and a reduction in the ability to establish such contacts (Jopek, 2018: 29). Excessive media use may result in less engagement in relationships with other people, as well as lower satisfaction from establishing social contacts (Wrona, 2014: 85). Aggression is yet another dangerous antisocial behaviour, which can be divided into reactive aggression, related to the process of relieving tensions and frustrations, and instrumental aggression, using force in order to obtain various benefits (Jopek, 2018: 30).

\section{Risks of the Internet}

The Internet is a particularly popular medium these days, which makes it a worthwhile object of analysis concerning the risks and dangers associated with media use, since being an Internet user involves dangers that do not concern other types of media and are therefore dangers specific to the Internet. The aforementioned aggression, which in relation to the Internet is referred to as electronic aggression, is one of such issues. Electronic aggression concerns "all acts of aggression carried out through information and communication technologies" (Jopek, 2018: 31). This phenomenon encompasses various kinds of violence, as well as several specific groups of other Internet users at whom it is directed. One variation of such violence is electronic bullying, or cyberbullying, which involves persistent aggressive behaviour aimed at harming another person or causing psychological discomfort 
(Jopek, 2018: 32). Cyberbullying comprises harassment, intimidation, blackmail and stalking using pictures, videos or text messages. The phenomenon of hate speech, especially racist and xenophobic messages, is yet another kind of electronic aggression (Jopek, 2018: 31-32). Another risk concerns access to inappropriate content, especially related to the sphere of sexuality - nudity, pornographic materials, sexualised messages, as well as incentivising the sharing of nude pictures (Wrona, 2014: 89-91). However, this also concerns materials depicting violence, vulgarity and cruelty (Jopek, 2018: 34). Another type of threat connected with the Internet concerns stealing and exploitation of data - hacking, identity theft and phishing. All the threats mentioned above, as well as others that are not included in this list, are referred to as social cyberpathologies, as they concern inappropriate online behaviours that pose a threat to people's mental health and proper social functioning (Jopek, 2018: 29).

\section{Conclusions}

Bogdan Suchodolski stated that "the most important thing for education today is to shape people so that they will be able to live in the conditions of modern civilisation, so that they will be able to cope with the tasks they will have to face, so that they will be able to take advantage of the opportunities for cultural development it provides, so that they will know what to strive for and how to do it, and so that they know where they should look for the joy of life" (Suchodolski, 1968: 16) and this thought seems particularly topical in this day and age. The media undoubtedly bring a new quality to our lives: they make it easier to establish and maintain social contacts and to take action thanks to the speed, accessibility and sheer multitude of information, tools and functions. However, all the advantages may turn into disadvantages if they are used in a careless manner. The opportunities and threats of the media indicated in this paper require constant analysis, especially in the context of developing solutions that will eliminate the negative effects of the influence of mass media. In order to be a conscious participant of virtual reality, one should keep in mind not only the basic safety rules concerning the protection of identity and data, but also proper information filtering, maintaining the balance between the use of online and offline tools, following the rules of online etiquette and strengthening one's critical thinking skills. Bearing in mind that media phenomena have a profound, often irreversible effect on their audience, the youngest recipients should develop their media competencies. "An appropriate and systematic media education aimed at children, youth and parents is an opportunity 
to prepare the information society for rational, correct and safe use of media, as well as a critical and conscious reception of content transmitted through them" (Nowicka, 2012a: 521). The key competence for becoming a responsible viewer and creator of the virtual world seems to be "preparing people to analyse, critically evaluate and create media texts, to identify sources of media texts, to interpret messages and values offered by the media, and to be able to choose the right media to convey one's own messages and relations aimed at specific audiences" (Nowicka, 2012a: 521), which is also one of the main tasks of media education.

In the words of John Paul II, "With the recent explosion of information technology, the possibility for communication between individuals and groups in every part of the world has never been greater. Yet, paradoxically, the very forces which can lead to better communication can also lead to increasing self-centredness and alienation. We find ourselves therefore in a time of both threat and promise." (John Paul II, 1999).

\section{Bibliography}

Huk T. (2011), Media w wychowaniu, dydaktyce oraz zarządzaniu informacją edukacyjna szkoty, Kraków.

John Paul II (1999), „Środki przekazu cenna pomocą dla tych, którzy szukają Ojca”. Orędzie Papieża Jana Pawła II na 33. Światowy Dzień Środków Społecznego Przekazu, https://www.paulus.org. pl/234,33-sdssp-jan-pawel-ii-1999, accessed: 28.05.2020.

Jopek A. (2018), Cyberpatologie społeczne wśród dzieci i młodzieży, [in:] J. Grubicka (ed.), Zagrożenia i bezpieczeństwo współczesnego człowieka w cyberprzestrzeni, Słupsk.

Media jako środowisko wychowawcze - rodzaje i specyfika wplywu, http://technikamedialna.blogspot. com/2010/08/2212-media-jako-srodowisko-wychowawcze.html, accessed: 31.05.2020.

Nowicka E. (2012a), Działania profilaktyczne wobec zagrożeń medialnych, [in:] W. Skrzydlewski, S. Dylak (eds.), Media, edukacja, kultura - w stronę edukacji medialnej, Poznań-Rzeszów.

Nowicka E. (2012b), Media w najbliższym środowisku dziecka, [in:] T. Lewowicki, B. Siemieniecki (eds.), Cyberprzestrzeń i edukacja, Toruń.

Omyła-Rudzka Z., Feliksiak M. (study) (2019), Wiarygodność mediów, Komunikat z badań, no. 70, CBOS, Warszawa, https://cbos.pl/SPISKOM.POL/2019/K_070_19.PDF, accessed: 31.05.2020.

Rogulska A. (2012), Media globalne - media lokalne. Zagadnienia z obszaru pedagogiki medialnej i edukacji regionalnej, Kraków.

Suchodolski B. (1968), Wychowanie dla przyszłości, Warszawa.

Wrona A. (2014), Ciemna strona sieci - zagrożenia internetowe oraz ich konsekwencje dla uczniów, [in:] J. Bednarek, A. Andrzejewska (eds.), Zagrożenia cyberprzestrzeni i świata wirtualnego, Warszawa. 